\title{
Cancer-associated adipocytes: key players in breast cancer progression
}

\author{
Qi Wu ${ }^{1,2,3+}$, Bei $\mathrm{Li}^{1+}$, Zhiyu $\mathrm{Li}^{1}$, Juanjuan $\mathrm{Li}^{1}$, Si Sun ${ }^{4^{*}}$ and Shengrong Sun ${ }^{1 *}$ (D)
}

\begin{abstract}
Adipocytes are one of the primary stromal cells in many tissues, and they are considered to play an active role in the tumor microenvironment. Cancer-associated adipocytes (CAAs) are not only found adjacent to cancer cells, but also communicate with cancer cells through releasing various factors that can mediate local and systemic effects. The adipocyte-cancer cell crosstalk leads to phenotypical and functional changes of both cell types, which can further enhance tumor progression. Indeed, obesity, which is associated with an increase in adipose mass and an alteration of adipose tissue, is becoming pandemic in some countries and it is now considered to be an independent risk factor for cancer progression. In this review, we focus on the potential mechanisms involved with special attention to the adipocyte-cancer cell circle in breast cancer. We envisage that besides having a direct impact on tumor cells, CAAs systemically preconditions the tumor microenvironment by favoring antitumor immunity. A better understanding of cancer-associated adipocytes and the key molecular events in the adipocyte-cancer cell crosstalk will provide insights into tumor biology and permit the optimization of therapeutic strategies.
\end{abstract}

Keywords: Breast cancer, cancer-associated adipocyte, exosome, miRNAs

\section{Introduction}

The tumor microenvironment (TME) is a heterogeneous ecosystem composed of infiltrating immune cells, mesenchymal support cells, and matrix components contributing to tumor progression. Adipocytes are the primary cellular components comprising the breast cancer $(\mathrm{BC})$ microenvironment, and emerging evidence indicates that adipocytes drive enhanced tumor progression through mutual and dynamic communication between tumor cells and adipocytes $[1,2]$. Specifically, normal adipocytes are driven into cancer-associated adipocytes (CAAs) by tumor cells and these tumor cells become metabolic parasites, which are identified by their seizing of metabolites such as ketone bodies, fatty acids, pyruvate, and lactate from stromal adipocytes [3-5]. This review will summarize the importance of CAAs in the biological features of tumor cells in terms of

\footnotetext{
* Correspondence: 59333173@qq.com; sun137@sina.com

${ }^{\dagger} \mathrm{Qi}$ Wu and Bei Li contributed equally to this work.

${ }^{4}$ Department of Clinical Laboratory, Renmin Hospital of Wuhan University, 238 Ziyang Road, Wuhan, Hubei, People's Republic of China

'Department of Breast and Thyroid Surgery, Renmin Hospital of Wuhan University, 238 Ziyang Road, Wuhan, Hubei, People's Republic of China Full list of author information is available at the end of the article
}

inflammation, metabolism, and exosomes and further investigate the potential mechanisms that underlie the dynamic communication between CAAs and BC cells, especially in obesity, which may result in neoteric therapeutic strategies. Addressing the clinical obstacles associated with obesity and metabolic syndrome will become increasingly important.

\section{CAAs secrete inflammatory factors that modify the behavior of breast cancer cells}

Breast adipocytes can be divided into three categories: mature adipocytes, preadipocytes, and adipose-derived stem cells (ADSCs). Limited studies have shown that there is a special type of adipocyte that exists in the surrounding matrix of invasive breast cancer [1]. Compared to normal adipocytes, this kind of adipocyte exhibits a series of characteristics, such as fibroblast-like phenotypes, smaller size, small and dispersed lipid droplets, overexpression of collagen VI, and low expression of adiponectin (APN) and other adipokines. This type of adipocyte is defined as cancer-associated adipocyte (CAA). CAAs secrete more chemokine ( $\mathrm{C}-\mathrm{C}$ motif) ligand 2 (CCL2) [6], chemokine (C-C motif) ligand 5 (CCL5) [7], 
interleukin-1 $\beta$ (IL-1 $\beta$ ), interleukin-6 (IL-6) [1], tumor necrosis factor-alpha (TNF- $\alpha$ ), vascular endothelial growth factor (VEGF), leptin [8], etc., which can promote the invasion and metastasis of breast cancer (Fig. 1).

\section{Chemokines}

\section{CCL2}

Chemokine ( $\mathrm{C}-\mathrm{C}$ motif) ligand 2 (CCL2), also known as MCP-1 (monocyte chemoattractant protein-1), is located on chromosome 17q12, and the protein is composed of 76 amino acid residues. In the tumor microenvironment, CCL2 can be produced and secreted into the extracellular environment by many cells, such as cancer cells, fibroblasts, tumor-infiltrating monocytes, and endothelial cells. CCL2 works by binding to the G-protein-coupled receptor $\mathrm{C}-\mathrm{C}$ motif chemokine receptors 2 and 4 (CCR2 and CCR4), and it is an effective inducible chemical factor for recruiting immune cells, especially monocytes, to the inflammatory region [9]. Santander et al. found that when E0771 breast tumor cells were co-cultured with macrophages and adipocytes, the expression of the chemokine CCL2 increased to recruit more adipocytes and monocytes/macrophages [10]. Tsuyada et al. found that breast cancer cells secrete cytokines that activate the signal transducer and activator of transcription 3 (STAT3) pathway in fibroblasts by activating the promoter of STAT3, which leads to an increase in the expression and secretion of CCL2. At the same time, in breast cancer

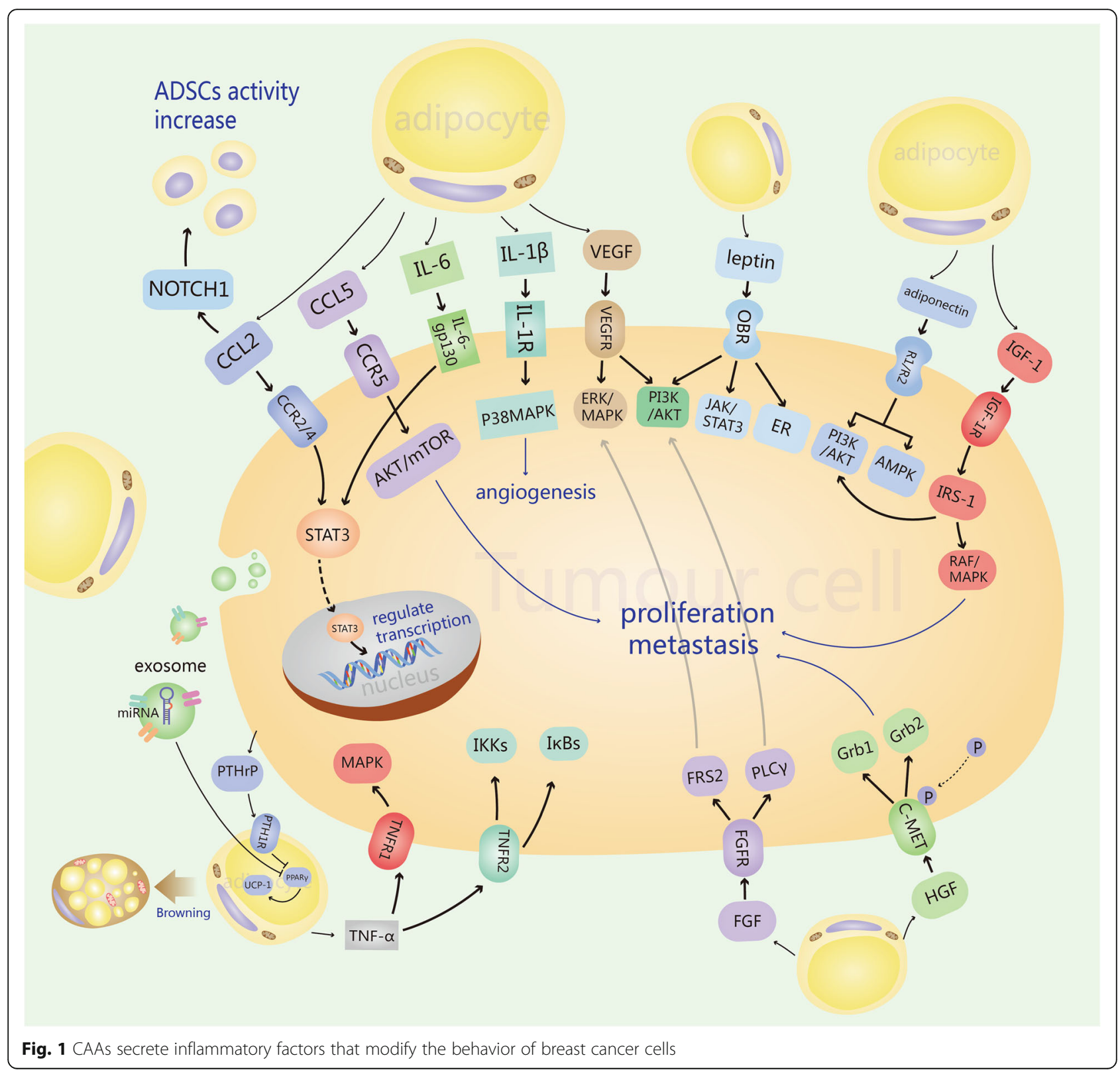


cells, CCL2 can also induce the expression of NOTCH1 and the conduction of its downstream signals, thus inducing the activity of cancer stem cells (CSCs) [11]. In addition, the expression of CCL2 was significantly associated with neovascularization [12, 13]. Arendt et al. explored the mechanism of CCL2 in promoting angiogenesis. It was found that the expression of CCL2 and IL-1 $\beta$ was elevated in the adipose tissue associated with obesity and co-induced the secretion of chemokine $(\mathrm{C}-$ $\mathrm{X}-\mathrm{C}$ motif) ligand 12 (CXCL12) in macrophages, which acted on blood vessels to enhance angiogenesis [14]. Their results also suggested that the mammary epithelial cells around the adipose tissue secreted CCL2, leading to the recruitment of macrophages and formation of the crown-like structures (CLS) associated with malignant progression of breast cancer. In conclusion, CCL2 mediates chemotaxis and angiogenesis by binding to CCR2 and CCR4.

\section{CCL5}

Chemokine ( $\mathrm{C}-\mathrm{C}$ motif) ligand 5 (CCL5, also known as RANTES) is located at chromosome $17 \mathrm{q} 12,8 \mathrm{kDa}$ and plays an important role in many physiological processes. CCL5 can be produced by various cells, such as breast cancer cells and mesenchymal stem cells, and is highly expressed in breast cancer tissue [15]. D'Espositol's study demonstrated that when MDA-MB-231 triple-negative breast cancer cells (TNBC) cells were co-cultured with human adipocytes, the level of CCL5 in the surrounding tissues increased, resulting in an enhanced invasion and metastasis ability of MDA-MB-231 cells [7]. Karnoub et al. discovered that breast cancer cells stimulate the secretion of CCL5 and that paracrine CCL5 reversibly binds to $\mathrm{C}-\mathrm{C}$ motif chemokine receptor 5 (CCR5) on the membrane surface of MDA-MB-231 cells to enhance the migration, invasion, and metastasis of breast cancer cells [16]. Many studies have shown consistently that the CCL5-CCR5 axis is related to the invasion and metastasis of breast cancer [17-19]. Velasco-Velázquez's study found that the CCL5-CCR5 axis is highly activated in TNBC- and human epidermal growth factor receptor-2 (HER2)-positive breast cancers and that CCR5+ cells respond to CCL5. When using the CCR5 inhibitors maraviroc and vicriviroc, the infiltration and invasion of breast cancer cells were reduced; this study also revealed that the invasion ability of CCR5+ cells isolated from breast cancer cells was 40 times greater than that of CCR5-cells [20]. Murooka et al. showed that CCL5 increases the proliferation and survival of MCF-7 cells overexpressing CCR5 in a mechanistic target of rapamycin (mTOR)-dependent manner [18]. Michael John Sax et al. explored the mechanism of the CCL5-CCR5 signaling pathway in promoting the metastasis of breast cancer. This study showed that inhibiting CCL5-CCR5 signaling in endothelial cells led to protein kinase B $(\mathrm{AKT}) / \mathrm{mTOR}$ pathway activation defects as well as vascular and tumor growth defects in vitro and in vivo [19]. Therefore, it is likely that the stromal cells secrete CCL5 into the tumor microenvironment and that CCL5, by binding to CCR5, activates the AKT/mTOR pathway and promotes tumor metastasis. Furthermore, CCL5 partly impairs triglyceride synthesis in adipocytes through its cognate receptors via down-regulating lipogenic enzymes and sterol regulatory element-binding protein-1 (SREBP-1) [21]. CCL5 could also recruit macrophages [22], Th1, and Th17 effector T cells [23] into TME to induce and maintain inflammatory microenvironment. Consequently, CCL5 may be a potential target for precise treatment of breast cancer, but the specific mechanism needs to be investigated further.

\section{Inflammatory factors \\ IL-6 and IL-1 $\beta$}

Interleukin-6 (IL-6) is a cytokine that participates in a variety of biological activities, such as immune regulation, hematopoiesis, and tumorigenesis [24]. There are cancer-associated adipocytes (CAA) around breast cancer tissue. When adipocytes are co-cultured with breast cancer cells, the expression and secretion of IL-6 in adipocytes increase, promoting the invasion and migration of cancer cells [25-27]. When IL-6R is blocked by antiIL-6R antibody, the metastasis of breast cancer induced by IL- 6 is reversed $[28,29]$. In addition, IL- 6 promotes the proliferation and survival of tumor cells, as well as angiogenesis, by regulating Janus kinase (JAK)/STAT3 signaling pathways [30]. In HER2-positive breast cancer, IL-6 can also induce the production and maintenance of breast cancer stem cells (CSCs) through nuclear factor kappa-B (NF-kB) and STAT3 signaling pathways, then promoting tumor progression [31]. When Notch, Wnt and transforming growth factor- $\beta$ (TGF- $\beta$ ) signaling pathways are activated, IL-6 also regulates self-renewal of breast cancer CSCs and promotes the survival and proliferation of CSCs [32]. Therefore, IL-6 promotes the invasion, metastasis, and angiogenesis of breast cancer mainly by activating JAK/STAT3 signaling pathway.

Blood monocytes, tissue macrophages, and other cells generate and release interleukin-1 $\beta$ (IL-1 $\beta$ ) into the extracellular environment, which has pro-inflammatory effects and participates in the proliferation, invasion, metastasis, and angiogenesis of breast cancer [33, 34]. Moreover, adipocytes cultivated with cancer cells show an altered phenotype that the expression of pro-inflammatory factors is increased, including IL-1 $\beta$ [1]. IL- $1 \beta$ has been identified as a potential predictor of bone metastasis in breast cancer patients. IL- $1 \beta$ increases the expression of osteoprotegerin (OPG, a promoter of invasion and metastasis of breast cancer) and induces its 
secretion by activating the $\mathrm{p} 38$ mitogen-activated protein kinase (MAPK) signaling pathway [35]. Upon binding to IL-1R1, IL-1 $\beta$ increases the expression of VEGF and its receptors on endothelial cells (ECs), while activation of p38MAPK signaling results in the migration of ECs and tube formation, both contributing to tumor angiogenesis [35].

\section{TNF- $a$}

Tumor necrosis factor-alpha (TNF- $\alpha$ ) is an important inflammatory factor in the tumor microenvironment that is generated by tumor cells and stromal cells. The serum TNF- $\alpha$ level is significantly elevated in breast cancer patients. Moreover, the gene expression level of TNF- $\alpha$ showed a 5 -fold increase in co-cultivated adipocytes [1], and the secretion of TNF- $\alpha$ was upregulated too [36]. TNF- $\alpha$ is considered as a potential biomarker of breast cancer growth and prognosis. TNF- $\alpha$ participates in multiple cellular signaling pathways by binding to receptors, which correlates with inflammation and survival of breast cancer [37]. Hagemann et al. confirmed that, in epithelial tumors, TNF- $\alpha$ stimulates the secretion of matrix metalloproteinases (MMP), thereby promoting the invasion of tumor cells [38]. Chua et al. showed that TNF- $\alpha$ enhanced the epithelial-mesenchymal transition of mammary epithelial cells, thus promoting the invasion and metastasis of breast cancer cells [39]. Another study also found that TNF- $\alpha$ induced the expression of VEGF to promote angiogenesis [40]. In addition, TNF$\alpha$ activates transcription factors and related genes and then stimulates the related cell signaling pathways, which promotes the proliferation of tumor cells [41]. Therefore, TNF- $\alpha$ plays an important role in tumor proliferation, angiogenesis, invasion, and metastasis [42].

\section{VEGF}

Vascular endothelial growth factor (VEGF), consisting of two $23 \mathrm{kD}$ single-chain proteins, has six isoforms and is widely expressed in tumor tissues. VEGF is highly upregulated in the breast tumor microenvironment, and VEGF/ VEGFR activates oncogenic signaling pathways, including the MAPK pathway and the phosphatidylinositol 3-kinase (PI3K)/AKT pathway, triggering the proliferation, survival, migration, and angiogenesis of breast cancer cells [43]. Overexpression of VEGF-A in adipocytes induces angiogenesis and the rapid appearance of brown adipocytes in white adipose tissue. VEGF-A-induced browning is not associated with IL-4, contrary to traditional cold-induced browning [44]. Moreover, when VEGF was knocked down, MDA-MB-231 cells showed shorter perimeters and more rounded morphologies. VEGF also stimulates the migration of breast cancer by forming filopodia via the neuropilin-1 (NRP1)/ARHGAP17/Cdc42, signaling pathway [45]. Although anti-VEGF therapy has already been applied in clinical treatments, there is unavoidable resistance to this therapy eventually. A recent study demonstrated that high levels of serum IL-6 and fibroblast growth factor-2 (FGF-2) contributed to the resistance of anti-VEGF therapy in obese breast cancer patients and mouse models. However, this resistance could be overcome by blockade of IL-6 [46]. Thus, VEGF plays a crucial role in tumor angiogenesis and metastasis.

\section{Adipokines \\ Leptin and adiponectin}

Leptin, by binding to the leptin receptor (OB-R), promotes breast cancer cells to proliferate and develop. The synthesis and plasma levels of leptin increase according to total adipose tissue mass, and leptin could also be produced by cancer-associated fibroblasts [47]. It has been reported that leptin levels are increased in the plasma of breast cancer patients, which correlates with higher grade, advanced tumor stages, and aggressive subtypes [36]. The generation and secretion of leptin were increased in cancer-associated adipocytes, compared to mature adipocytes [36]. Leptin activates estrogen receptor (ER) signaling, as well as the JAK/STAT3 and PI3K/AKT signaling pathways, promoting the proliferation of breast cancer cells [36]. Moreover, leptin increases the expression of cyclin D1 and cyclin-dependent kinase 2 [48], which accelerates the cell cycle of breast cancer cells. Leptin and IL-1 promote the expression of VEGF/ VEGFR, in the meantime, leptin upregulates IL-1/IL-1R signaling both mRNA and protein levels, playing a pro-angiogenic role together [49]. Leptin could also promote proliferation in breast cancer cells in vitro via steroid receptor coactivator (SRC)-1/STAT3 signaling pathway [50].

The secretion of adiponectin decreases in CAA [36]. Adiponectin acts as a protective factor against tumor progression by binding to the adiponectin receptors AdipoR1 and AdipoR2. Adiponectin inhibits the growth and invasion of breast cancer cells and induces cell apoptosis by triggering Adenosine 5'-monophosphate (AMP)-activated protein kinase (AMPK) signaling and inhibiting PI3K/AKT signaling [36].

It seems that adiponectin acts in contrast to leptin, and the adiponectin to leptin ratio is used to describe this relationship. During the development of obesity, pre-adipocytes differentiate incorrectly, and the generation of hypoxia-inducible factor-1 (HIF-1) is induced by hypoxia to increase the expression of leptin and inhibit the expression of adiponectin. Therefore, the adiponectin to leptin ratio is decreased in obesity-related adipose tissue [51].

\section{Parathyroid hormone-related protein}

Parathyroid hormone-related protein (PTHrP) is processed into at least three different peptide products and generated by several kinds of cancer cells. PTHrP could 
activate a variety of signaling pathways in cells by binding to parathyroid hormone $(\mathrm{PTH}) / \mathrm{PTHrP}$ receptor (PTH1R). In metabolic terms, PTHrP not only inhibits adipogenesis by downregulating peroxisome proliferatoractivated receptor $\gamma$ (PPAR $\gamma$ ) expression [52] but also triggers adipose tissue browning by upregulating the expression of thermogenic genes such as uncoupling protein 1 (UCP1) [53]. Therefore, this suggests that tumor cell-derived PTHrP competes for limited nutrition to inhibit adipogenesis and obtains further energy from mature adipocytes by inducing lipolysis. Moreover, PTHrP could enhance bone metastasis, which may be closely related to bone marrow adipocytes [54]. Deleting PTH1R in the bone marrow adipose tissue contributes to the elevated expression of receptor activator of nuclear factor kappa B ligand (RANKL) and generates classic adipogenic markers which can induce mesenchymal stem cells to differentiate into mature adipocytes [55]. Therefore, it is speculated that tumor-originated PTHrP could result in cancer cachexia and promote bone metastasis by remodeling adipocytes.

\section{The metabolic reprogramming of CAAs drives cancer progression}

Upon interaction with breast cancer cells, adipocytes were initially identified as a tremendous energy storage that provides high-energy metabolites [10]. The metabolic reprogramming of CAAs can be attributed to their potential high tumor-promoting ability. It is speculated that tumors can induce reprogramming of metabolic synergy in adipocytes and adapt to intracellular metabolic processes to support proliferation through dynamic interactions between breast cancer cells and CAAs. In addition, the metabolic reprogramming that occurs in CAAs involves the metabolic regulation of almost all macronutrients, such as carbohydrates, lipids, and amino acids (Fig. 2).

\section{Glycolysis and monocarboxylate extrusion}

To meet the extreme needs of energy of dividing cells, alterations happen in the metabolism of all macromolecules, such as proteins, carbohydrates, and lipids, in cancer cells [56]. As described in the "Warburg effect" [57], glycolysis increases in tumor cells despite the presence of oxygen [58]. Aerobic glycolysis provides the advantage of biosynthesis for tumor cells, and high-throughput substrates for glycolysis can efficiently divert carbon to key subsidiary biosynthetic pathways [56]. Furthermore, cancer has heterogeneity in the genetic and microenvironmental parameters that influence cell metabolism. The heterogeneity in tumor metabolism is not only demonstrated in the tumor itself, but also highlight the strong influence of the tumor microenvironment. The extent of tumor heterogeneity among different metabolic stages predicts metastatic specific organs. For example, cancer cells metastasized to the brain usually have flexible metabolic ability to utilize different fuels, such as acetate. And cancer cells metastasized to the liver could maximize the energy resources available to meet the energy demands [59]. However, previous studies on tumor metabolism have paid much attention to cancer cells themselves, ignoring different tumor "compartments" or mimicking of the tumor microenvironment. Recent studies have shown that in addition to cancer cells, different metabolic compartments, such as CAAs, in the tumor microenvironment play essential roles in the process [3, 60-62]. Glycolytic stromal cells promote tumor growth in breast cancer [63, 64]. The absence of Cav-1 is thought to be a hallmark of metabolic stress and is associated with poor survival in breast cancer [65]. Likewise, our results demonstrated that adipocytes co-cultivated with tumor cells exhibited increased UCP1 and monocarboxylate transporter 4 (MCT4) levels and reduced Cav-1 expression compared with single cultivation [66]. UCP1, which is generated only in beige/brown adipocytes, is also elevated in the adipose tissue close to breast cancer tissue [67]. Furthermore, increased expression of UCP1 leads to increased lipid mobilization and energy expenditure in vivo. Conversely, the activation of $\mathrm{UCP} 1+$ cells significantly decreases tumor development [67, 68]. In addition, monocarboxylate transporters (MCTs), which are transmembrane proteins, mediate the transport of diverse monocarboxylates, including lactate, ketones, and pyruvate and are related to poor prognosis in breast cancer. Of the MCTs, MCT1 and MCT2 are responsible for the uptake lactic acid to gain energy, while MCT4 facilitates lactic acid efflux to maintain a stable intracellular $\mathrm{pH}[69,70]$. Our results indicated that the overexpression of MCT1 is observed in hormone receptor-negative and high-proliferative subtypes and that when MCT4 is overexpressed in adjacent adipose tissue, the association between MCT1 expression and poor prognosis of breast cancer is further confirmed [71]. Moreover, it is clear that high expression of MCT2 in primary mammary-derived adipocytes (MGDAs) promotes the growth of breast cancer cells both in vitro and in vivo [72]. Meanwhile, MCT1 is a marker of mitochondrial metabolism (oxidative phosphorylation, OXPHOS), which is involved in the uptake of monocarboxylates and predominantly transports lactate into cells $[69,70]$. Mitochondrial metabolism is more efficient and produces more adenosine triphosphate (ATP) to promote tumor proliferation and metastasis. In addition, the absence of caveolin 1 (Cav-1, caveolae protein) promotes aerobic glycolysis of stromal cells, as well as the secretion of energy-rich metabolites (for example, lactate and pyruvate), which are considered as energy resources for cancer cells and provide fuel for the mitochondria of 


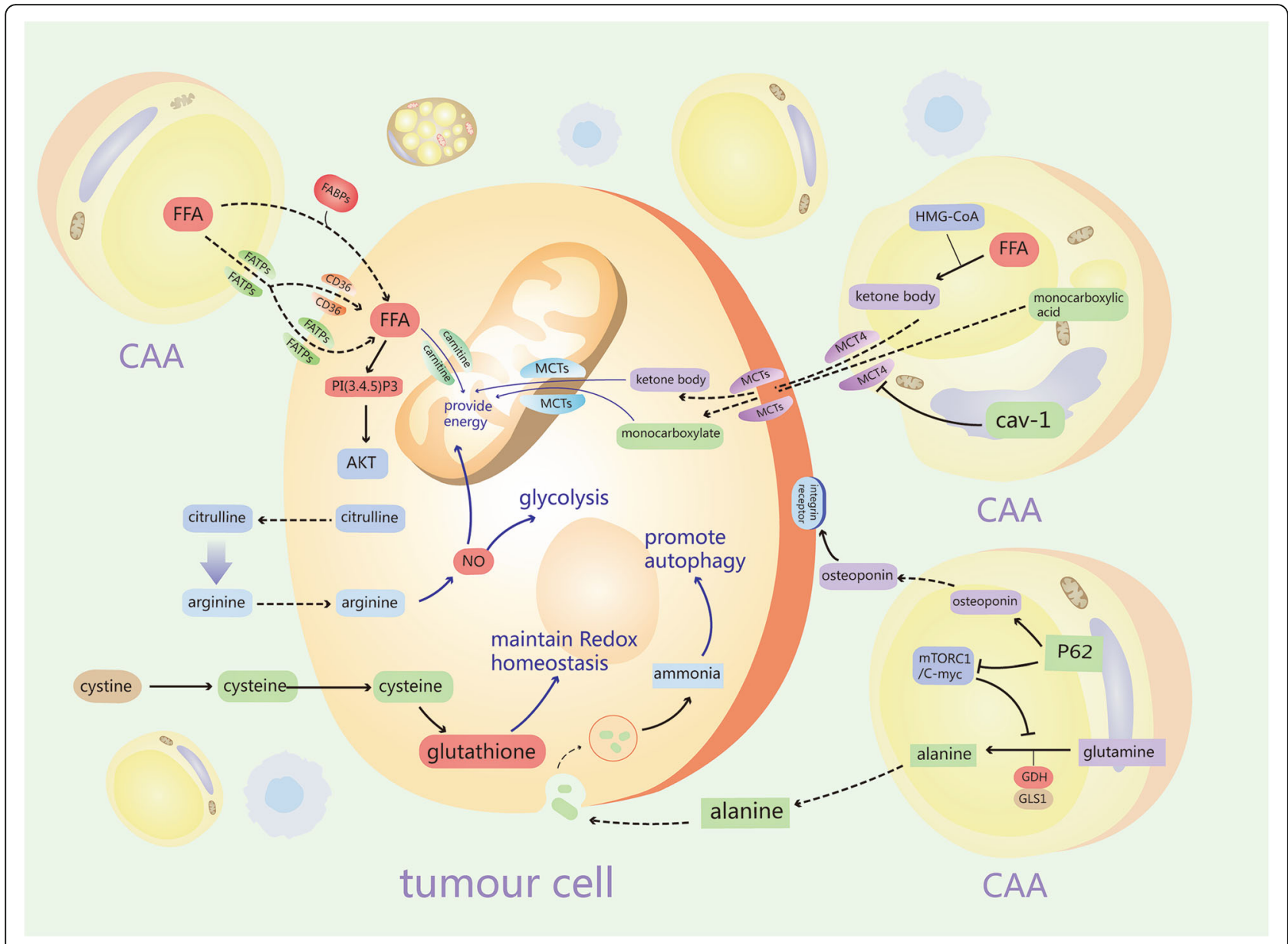

Fig. 2 The metabolic reprogramming of CAAs promotes cancer progression

adjacent cancer cells [73, 74]. Mechanistically, hypoxia induces the loss of Cav-1, which targets the MCT4 gene and upregulates its expression.

Overall, it is probably unsurprising that metabolic coupling has been formed between tumors and CAAs though the existence of a "monocarboxylate shuttle" in tumor-stromal interactions.

\section{Fatty acids and ketone bodies}

Mammary fat consists of large lipid droplets, regulates lipid metabolism, and is a major component of energy storage. Cancer cells often invade the adipose tissue and induce adipocytes to release free fatty acids (FFA), which are absorbed by cancer cells and are used to produce ATP and facilitate tumor growth [3, 75, 76]. It is now widely recognized that FFAs may promote cancer progression through multiple mechanisms [77]. First, the sources of FFAs can act as structural units for newly synthesized membrane phospholipids and determine the phospholipid composition of membranes. Cancer cell membranes become enriched with saturated and/or mono-unsaturated fatty acids by enhancing de novo lipogenesis. In addition, due to the denser packaging of saturated lipids, increased lipogenesis also changes lateral and transverse membrane dynamics, resulting in cancer cells that are more resistant to oxidative stressinduced cell death and a limited uptake of drugs [77]. FFAs may also be used to supply energy for cells. Some specific types of tumors exhibit upregulated fatty acid uptake and elevated dependence on FFA $\beta$-oxidation as their main energy source [60-62, 78, 79]. Ultimately, FFAs can also be applied to the biosynthesis of a series of lipid-signaling molecules that promote tumorigenesis. For example, phosphatidylinositol-3,4,5-trisphosphate [PI $(3,4,5) \mathrm{P} 3]$, a lipid messenger formed by the activation of PI3K that activates AKT to regulate cell proliferation and survival, plays a particularly important role in cancer progression [80]. Our studies showing that fatty acid transports such as CD36 and fatty acid transport protein-1 (FATP1) are primarily detected in most breast cancer tissues located adjacent to the adipose tissues support this idea; in contrast, the expression of fatty acid transports was elevated in adipocytes that were co-cultivated with breast cancer cells compared to the 
expression in adipocytes cultivated alone. Furthermore, adipocyte-induced CD36 and FATP1 expression contribute to cancer progression by fueling or signaling [61, 78, 81]. Fatty acid-binding proteins (FABPs) are also a series of proteins that serve as intracellular fatty acid transporters that regulate lipid trafficking and cellular responses [82]. The expression of FABP4 was found in ovarian cancer and acute myeloid leukemia at the adipocyte-tumor cell margin, providing fatty acids for rapid tumor growth [62, 79]. However, FABP4 expression is downregulated in the fat tissue surrounding breast cancer [1], while circulating, FABP4 levels in plasma are increased in breast cancer patients, and exogenous FABP4 accelerates breast cancer cell proliferation [83, 84]. Furthermore, FABP4 is also released from these macrophages, and the expression of fatty acid-binding proteins in tumor-associated macrophages (TAM) promotes breast cancer progression [82, 85], suggesting that macrophages, not adipocytes, may be the main source of FABP4 in patients with breast cancer. Moreover, our results indicated that FABP5 mRNA is highly expressed in adipocytes that were co-cultured with breast cancer cells [66]. FABP5 has also been shown to be overexpressed at the invasive front of the breast tumor and linked to poor survival [86, 87]. Similarly, Wang and colleagues described a novel mechanism in which FFAs were released by adipocytes after lipolysis induced by tumor secretions and were transferred into tumor cells to enhance FFA $\beta$-oxidation [3], in which FFA transformation maybe attributed to FABP5 high expression [86]. Thus, fatty acid metabolism patterns may alter based on the tissue-specific characteristics in cancers that are produced in the vicinity of adipose tissues and translated into the expected availability of these nutrients.

Ketone bodies are catabolites produced by fatty acid $\beta$ oxidation or aerobic glycolysis. Ketone bodies are produced and released by stromal cells and may upregulate cancer cell invasion by increasing OXPHOS [69, 88]. Moreover, it is well known that tumor cells need ketones as components of the tricarboxylic acid (TCA) cycle. Additionally, ketones are an ideal substrate for ATP production in invasive cancer cells because ketone bodies produce more ATP and consume less oxygen than glucose $[89,90]$. For instance, breast cancer cells that were co-cultured with CAAs overexpress MCT2, inducing H3K9 acetylation, upregulating several tumor-promoting genes, and increasing the uptake of $\beta$-hydroxybutyrate to promote tumorigenesis [72]. CAAs are related to ketogenesis. The rate-limiting step in ketogenesis is the generation of 3-hydroxy-3-methyl glutaryl coenzyme A (HMG-CoA) by 3-hydroxybutyrate dehydrogenase 1 (BDH1), 3-hydroxymethyl-3-methylglutaryl-CoA lyase (HMGCL), and 3-hydroxy-3-methylglutaryl-CoA synthase 2 (HMGCS2) [88, 91]. Moreover, our results indicated that adipocytes co-cultivated with MDAMB-231 cells exhibited increased activity of several rate-limiting enzymes, as exemplified by the strong increase in the mRNA levels of BDH1, HMGCL, and HMGCS2 [66]. Consistently, HMGCS2 was overexpressed in fibroblasts to accelerate breast cancer xenograft growth [88, 92]. In contrast, cancer cells exhibit high ketolytic activity and utilize ketone bodies by increasing acetyl-CoA acetyltransferase (ACAT) and 3-oxoacid CoAtransferase (OXCT) expression. Our results also showed that overexpression of ACAT 1/2 and OXCT 1/2 mRNA was observed in breast cancer cells in the presence of adipocytes. Similarly, high expression of OXCT or ACAT stimulates breast cancer growth and metastasis and is related to worse outcomes in breast cancer patients [88, 92, 93]. Furthermore, UCP1 expression has been observed to be increased in cancer-associated fibroblasts (CAFs) adjacent to breast cancer tissue, resulting in lipid mobilization and increasing ketone body production, which promotes tumor growth by supplying high-energy nutrients in a paracrine manner [94]. In addition, high expression of UCP1 was detected specifically in the resident adipose tissue and in adipocytes that were co-cultivated with tumor cells, demonstrating that CAAs may have a similar mechanism as that of CAFs.

In summary, FFAs and ketones play the role of paracrine high-energy nutrients in the "reverse Warburg effect" and can act as monocarboxylates to provide the energy required for cancer biomass synthesis, migration, and invasion.

\section{Amino acids}

Amino acids, such as glutamine, glycine, serine, and proline, play important roles in cancer metabolic synergy $[89,95,96]$. In human breast cancer, asymmetric metabolism of these amino acids is also present between cancer and stromal cells.

Glutamine is an important amino acid for the mitochondrial metabolism of cancer cells and replenishes intermediate catabolites for the TCA cycle. Glutamine can be a pivotal source of the TCA cycle intermediates and ATP in cancer cells [97, 98]. Glutamine is also the substrate of the antioxidant glutathione and contributed to nucleotide synthesis [98, 99]. Recently, it has been recognized that stromal cells generate glutamine to promote cancer growth [100]. More recent studies on amino acids in the tumor microenvironment have demonstrated that glutamine can be obtained by cancer cells from the tumor microenvironment by increasing the activity of glutamate ammonia ligase, a key enzyme in glutamine synthesis [101]. Increased glutamine exposure induces the upregulation of glutamine importers and mitochondrial biogenesis in cancer cells, which results in resistance to cancer therapy [100, 101]. Likewise, glutamine could be provided by cultured astrocytes to brain 
cancer cells [102]. Furthermore, the secretion of alanine and ammonia accompanies glutamine catabolism. Stromaassociated pancreatic stellate cells could release alanine by relying on autophagy, and then cancer cells take up alanine as an alternative carbon source [103]. Ammonia facilitates autophagy and promotes autolysosomes to diffuse [104]. Cancer cells usually exhibit higher expression levels of glutamine metabolism enzymes such as glutaminase-1 (GLS1) and glutamate dehydrogenase (GDH) than those of stromal cells [105]. Mechanistically, several tumor stromal p62 levels decreased, which resulted in decreased consumption of glutamine through the mTORC1/c-MYC signaling pathway. Similarly, p62 deletion in adipocytes increased tumorigenesis through osteopontin secretion, and inhibition of mTORC1 caused adipocytes to regularly shut down energy utilization, which increased nutrient availability for cancer cells [106].

Adipose stromal cells in the tumor microenvironment have also been shown to metabolize symbiotically with cancer cells through arginine metabolis [107]. Citrulline and nitric oxide are generated by cancer cells by consuming and catabolizing arginine, which is mediated by inducible nitric oxide synthase. Nitric oxide not only suppresses oxidative phosphorylation but also facilitates glycolytic activity and proliferation. The citrulline produced in cancer cells is secreted into the extracellular matrix, taken up by stromal adipocytes, converted back into arginine, and released for cancer cells, thus forming this symbiotic metabolic shuttle. Cysteine, as one of the three amino acids of glutathione, contributes greatly to maintaining the redox balance. Given that cancer cells are often subjected to intense redox stress, especially when exposed to chemotherapies, the need for cysteine increases [108]. In blood, cysteine is mainly found in the form of oxidized dimers. Accordingly, cystine is consumed in cancer-associated bone marrow stromal cells to generate cysteine, which is released and then transported into the chronic lymphoid leukemia cells via neutral amino acid transporters. This cysteine in leukemia cells is used to generate glutathione and protect cancer cells from chemotherapy-induced cell death. Similarly, it was reported that ovarian CAFs secreted cysteine and glutathione to adjacent ovarian cancer cells, promoting chemoresistance [109]. In addition, it is reasonable to propose that the release of amino acids mediated by adipocytes may be a pathogenic factor related to worse survival outcomes.

\section{Exosomes interconnect cancer and cancer- associated adipocytes to promote tumor progression}

Exosomes, a kind of small extracellular vesicle (30-100 $\mathrm{nm})$, are derived from the endosomal compartments of almost all cells [110]. Moreover, exosome contents consist of mRNA, ncRNA, transcription factors, proteins, and lipids, and exosomes have been implicated in cell communication and the modulation of cell biology by trafficking these materials into target recipient cells [111]. In addition, exosomal miRNA profiles parallel those of the originating tumor cells [112]. It is clear that miRNA dysregulation plays a primary effect on tumor initiation, progression, and metastasis [113]. Although exosomes secreted from tumor cells are associated with tumor proliferation and metastasis [114], their potential effects on the neoplastic transformation of adipocytes remain unknown. Thus, we have demonstrated that the underlying mechanism involves the delivery of special onco-miRNAs such as miRNA-144, miRNA-126, and miRNA-155 from breast cells to adipocytes in the breast cancer microenvironment via exosomes, resulting in the conversion of resident adipocytes to CAAs [66]. Our study revealed that exosomal miRNA-144, acting as an important communicator between tumor cells and adipocytes, promoted the beige/brown differentiation of adipocytes, and exosomal miRNA-126 also played a vital role in the metabolic reprogramming of adipocytes [66]. In addition, exosomal miRNA-155 promotes lipolysis in adipocytes and facilitates an aggressive phenotype of tumor cells [115]. Moreover, exosomal miRNA-122 was highly expressed but has not been extensively studied, and exosomal miRNA-122 suppresses the uptake of glucose in premetastatic niche cells by decreasing the glycolytic enzyme pyruvate kinase, thereby facilitating disease progression [116]. Likewise, the expression of miRNA-105 secreted by breast cancer activates MYC signaling in CAFs and CAAs to induce a metabolic program. Furthermore, miR-105-reprogrammed CAFs enhance the metabolism of glucose and glutamine, fueling neighboring cancer cells in sufficient nutrient conditions, while these CAFs convert metabolic wastes such as lactic acid and ammonium into energy-rich metabolites in situations of nutrient deficiency. Therefore, the metabolic reprogramming of stromal cells mediated by miR-105 promotes sustained tumor growth by modulating the shared metabolic environment [117]. Similarly, HepG2, a hepatocellular carcinoma cell line, secreted exosomes, including some special proteins, activated phosphokinases and the NF- $\mathrm{kB}$ signaling pathway of adipocytes to promote tumor growth and angiogenesis and recruited more macrophages [118]. Moreover, this indicated that exosomal adrenomedullin originating from pancreatic cancer cells induces lipolysis by phosphorylating hormone-sensitive lipase in subcutaneous adipose tissue, which may be involved in the formation of CAAs [119]. As to circular RNA, exosomes released from gastric cancer cells deliver ciRS-133 (circular RNA sponge for miRNA-133) to pre-adipocytes, modulating the differentiation of pre-adipocytes to brown-like adipocytes through 
activating PR domain containing 16 (PRDM16) and inhibiting miRNA-133, which upregulates the expression of UCP1 [120]. In terms of exosome-released long noncoding RNAs, high expression of HOTAIR is found in multiple tumor tissues [121, 122]. Interestingly, cancer cells transport HOTAIR via exosomes to endothelial cells to stimulate angiogenesis by increasing VEGFA expression [123]. Although it has not been extensively shown that the effect of cancer-secreted long noncoding RNAs occurs in adipocytes, it should be further explored in future research. Taken together, these results show that exosomederived contents are probably exploited by cancer cells as a sort of "signal" to convert the cells in the microenvironment into a pro-tumor niche.

Many studies have concentrated on exosomes derived from cancer cells that promote tumor proliferation and metastasis [114], while there is little work focused on exosomes from CAAs. It is evident that adipocyte exosomes are specifically enriched in proteins involved in fatty acid oxidation (FAO) and induce tumor cell metabolism reprogramming, which is beneficial for FAO stimulation of melanoma cell migration and invasion [124]. In conditions of obesity, the increased number of exosomes secreted and their effect on tumor aggressiveness contributed to the amplification of the harmful symbiosis between adipocytes and cancer cells [124]. In addition, the protein level of MMP3 in lung tumor tissues of obese patients is higher than that of nonobese patients. Mechanistically, adipocyte-derived exosomes increase MMP3, and MMP3 is transferred to lung cancer cells. MMP3 increases the activity of MMP9 in lung cancer cells and facilitates the invasion of cells in vitro and in vivo [125]. In terms of dysfunctional exosomal miRNAs, exosomal miR-21 expression was predominantly upregulated and potentially prognostic in multiplicate tumor stroma, such as triple-negative breast cancer and colorectal cancer $[126,127]$. Equally higher levels of miR21 in CAAs were observed, and miR-21 is transported from CAAs to cancer cells, inhibiting the apoptosis of ovarian cancer cells and producing chemotherapy resistance by combining with its direct new target apoptotic protease activating factor-1 (APAF1) [128]. miR-210, induced by HIF-1a, is overexpressed in tumor cells and in the tumor microenvironment and shows an inverse correlation with survival in patients with breast cancer [129, 130]. Meanwhile, miR-210 released from adipose-derived stem cells promoted the proliferation, invasion, and migration of endothelial cells by targeting runt-related transcription factor 3 (RUNX3), suggesting that exosomal miR-210 may mediate tumor angiogenesis [131]. Therefore, the exosome contents released by CAAs are tumor-supportive factors that induce drug resistance.

In summary, exosomes serve as a novel method of transmitting information among cells and play a pivotal role in the symbiosis between adipocytes and multiple types of cancer cells by regulating angiogenesis, immunity, and metabolism (Table 1).

\section{Adipocytes play an important role in cancer Adipocytes are mediators between obesity and cancer} Adipocytes are the main matrix cell type in breast tissue. Because adipocytes surround breast cancer cells closely, the role of adipocytes in the evolution of breast cancer has recently been the focus of more attention. Most of the theoretical basis for studying the role of adipocytes in facilitating breast cancer evolution is associated with epidemiological evidence, suggesting a lower survival rate in obese breast cancer patients [3]. A key point is that we cannot identify whether the influence of adipocytes on breast cancer in obese individuals is different from that in normal or lean individuals based on the significant differences in adipocyte biology between thin and obese individuals, such as secretory protein spectrum changes, adipocyte size, and insulin sensitivity [4]. A laboratory study found that, compared with normal or thin women, the proliferation ability of MCF-7 cells increased when cultured with the conditioned media of adipocytes from obese women (body mass index (BMI): $30-35 \mathrm{~kg} /$ $\mathrm{m}^{2}$ ) [5]. Another study revealed that the estrogendependent cell E0771 in the mammary fat pad of mice fed a high-fat diet (a dietary-induced obesity (DIO) and hyperinsulinemia model) had a larger allograft volume than animals fed a normal diet [6]. These two studies showed the specific effects of obesity on breast cancer cell proliferation, whereas few studies have focused on exploring the mechanism by which the obese environment affects the progression of breast cancer. Although adipocytes may be the mediator between obesity and breast cancer, the specific mechanism remains to be elucidated.

\section{Adipocytes are a pivotal immunomodulatory factor in cancer}

Moreover, the expression of programmed death-ligand 1 (PD-L1) in adipocytes prevents the anti-tumor function of CD8+ T cells. The lipogenesis inhibitor then selectively reduces PD-L1 expression in the adipose tissue and enhances the anti-tumor efficacy against PD-L1 or antiPD-1.

Adipocytes contribute to immunosuppressive effects to avoid tumor elimination by the host antitumor immunity. Interestingly, the expression of PD-L1 has been shown to be significantly elevated in mature adipocytes compared to the level in preadipocytes. The expression of PD-L1 in adipocytes prevents the anti-tumor functions of $\mathrm{CD} 8+\mathrm{T}$ cells. Then, the adipogenesis inhibitor selectively decreases the expression of PD-L1 in the adipose tissue but enhances the antitumor efficacy of anti-PD-L1 or anti-PD-1 [132]. Moreover, UCP-1 was 
Table 1 Exosomes emerge as an intercellular shuttle between cancer cells and CAAs

\begin{tabular}{|c|c|c|c|}
\hline miRNA & Tumor/cell & Mechanism & References \\
\hline $\begin{array}{l}\text { miRNA- } \\
144\end{array}$ & Breast cancer & $\begin{array}{l}\text { miR-144 from cancer cells is able to target the MAP3K8 gene and reduce the phosphorylation level of } \\
\text { ERK1/2, which leads to a decrease in the phosphorylation level of PPARY S273 in adipocytes, ultimately } \\
\text { leading to an increase in the expression of UCP1. }\end{array}$ & [66] \\
\hline $\begin{array}{l}\text { miRNA- } \\
126\end{array}$ & Breast cancer & $\begin{array}{l}\text { miR-126, derived from breast cancer cells, can target the IRS-1 gene to downregulate the expression of } \\
\text { glut4 in adipocytes, which leads to a decrease in glucose uptake of adipocytes. And then AMPK is } \\
\text { activated and protein levels of HIF-1a and MCT4 are increased, resulting in an increase of glycolysis and } \\
\text { the secretion of metabolites, such as lactic acid and pyruvic acid. }\end{array}$ & [66] \\
\hline $\begin{array}{l}\text { miRNA- } \\
155\end{array}$ & Breast cancer & $\begin{array}{l}\text { miR-155 promotes beige/brown differentiation and remodels metabolism in adipocytes by } \\
\text { downregulating the PPARy expression. }\end{array}$ & [114] \\
\hline $\begin{array}{l}\text { miRNA- } \\
122\end{array}$ & Breast cancer & $\begin{array}{l}\text { miR-122 suppresses the uptake of glucose in premetastatic niche cells by decreasing the glycolytic enzyme } \\
\text { pyruvate kinase, thereby facilitating disease progression. }\end{array}$ & [115] \\
\hline $\begin{array}{l}\text { miRNA- } \\
105\end{array}$ & $\begin{array}{l}\text { Breast cancer } \\
\text { Hepatocellular } \\
\text { carcinoma } \\
\text { Pancreatic cancer }\end{array}$ & $\begin{array}{l}\text { miR-105 activates MYC signaling in CAFs and CAAs to induce a metabolic program. And miR-105- } \\
\text { reprogrammed CAFs enhance the metabolism of glucose and glutamine, fueling neighboring cancer cells } \\
\text { in sufficient nutrient conditions, while these CAFs convert metabolic wastes such as lactic acid and } \\
\text { ammonium into energy-rich metabolites in situations of nutrient deficiency. }\end{array}$ & [116-118] \\
\hline $\begin{array}{l}\text { ciRS- } \\
133\end{array}$ & Gastric cancer & $\begin{array}{l}\text { Exosomes released from gastric cancer cells deliver ciRS- } 133 \text { to pre-adipocytes, modulating the } \\
\text { differentiation of pre-adipocytes to brown-like adipocytes through activating PRDM16 and inhibiting } \\
\text { miRNA-133. }\end{array}$ & [119] \\
\hline $\begin{array}{l}\text { miRNA- } \\
21\end{array}$ & $\begin{array}{l}\text { Breast cancer } \\
\text { Colorectal cancer } \\
\text { Ovarian cancer }\end{array}$ & $\begin{array}{l}\text { miR-21 is transported from CAAs to cancer cells, inhibiting the apoptosis of ovarian cancer cells and } \\
\text { producing chemotherapy resistance by combining with its direct new target APAF1. }\end{array}$ & [125-127] \\
\hline $\begin{array}{l}\text { miRNA- } \\
210\end{array}$ & Endothelial cell & $\begin{array}{l}\text { miR-210 released from adipose-derived stem cells promoted the proliferation, invasion and migration of } \\
\text { endothelial cells by targeting RUNX3, suggesting that exosomal miR-210 may mediate tumor angiogenesis. }\end{array}$ & [130] \\
\hline
\end{tabular}

overexpressed in cancer-associated fibroblasts resulting in the release of ATP-rich vesicles by activating autophagy [94], and our study verified that UCP-1 was also highly expressed in cancer-associated adipocytes after the uptake of tumor exosomes [115]. In obese models, ATP promotes a Th17 polarizing microenvironment by activating the P2X7 receptor pathway and increases the levels of IL-1 $\beta$, IL-6, and IL-17 [133]. Moreover, IL-1 $\beta$ and IL-6 are also elevated in the tumor-adipocyte microenvironment [1] and interact with adipocytokines to aggravate tumor metastasis [134]. Meanwhile, crown-like structures (CLS) are characterized by adipocytes around infiltrating macrophages, and the CLS of the breast is found in nearly $50 \%$ of patient samples and is associated with lower survival [135]. ATP also increased the synthesis and release of CCL2 through activated P2Y2 receptors and attracted macrophages to the surrounding adipocytes [136]. Taken together, these findings imply that tumors may induce the release of ATP from stromal adipocytes to regulate the immune microenvironment and favor cancer progression.

\section{Potential drugs targeting CAAs}

Inflammatory factors (CCL5, IL-6, etc.) and transporters (MCT1, CD36, etc.) are potential targets for breast cancer treatment. So far, there have been some targeted treatments used in the clinical practice or for clinical and preclinical studies, such as Cenicriviroc (inhibitor of CCR2) inhibiting CCL2 [137, 138], Maraviroc (inhibitor of CCR5) inhibiting CCL5 [139], Tocilizumab (monoclonal antibody of IL-6R) [140], Canakinumab (monoclonal antibody of IL-1 $\beta$ ) [141], Infliximab (monoclonal antibody of TNF- $\alpha$ ) [142-144], Bevacizumab (monoclonal antibody of VEGF-A) [145], AZD3695 (inhibitor of MCT1) [146], Nivolumab (monoclonal antibody of PD1) [147], and Durvalumab and Avelumab (monoclonal antibodies of PD-L1) $[148,149]$ (Table 2). There are still many targets, such as inhibitor of exosomes, worth to be investigated for breast cancer precise therapy.

\section{Conclusion}

In the microenvironment of breast cancer, the expression and secretory spectrum of inflammatory mediators of adipocytes are changed, and the secretion of chemokines CCL5 and CCL2 and the inflammatory factors IL- 6 and TNF- $\alpha$ are increased, which further promotes the proliferation and invasion of tumor cells and the formation of neovascularization. It has been shown that the inflammatory microenvironment of breast cancer is an important driving factor for the progression of the disease and may become a potential target for new treatments. The current research has demonstrated that, especially in obese individuals, tumor cells and adipocytes have a clear clinical relevance, which helps to deepen our understanding of the mechanism of breast cancer. New drugs can be developed to target adipocytes and/or cancer cells directly or can be used in adjuvant therapy to achieve the maximum effect of existing treatment. Because obesity can affect the incidence and progression of 
Table 2 Potential targets for breast cancer precise therapy

\begin{tabular}{|c|c|c|c|c|}
\hline Agent & Target & In vitro effect & Preclinical and clinical effects & References \\
\hline Cenicriviroc & CCR2 & Inhibitor of CCR2 & $\begin{array}{l}\text { Inhibition of monocyte recruitment, Prevent virus from } \\
\text { entering into a human cell }\end{array}$ & {$[137,138]$} \\
\hline Maraviroc & CCR5 & Inhibitor of CCR5 & Blockade the HIV from entering macrophages and T cells & [139] \\
\hline Tocilizumab & $\mathrm{IL}-6 \mathrm{R}$ & $\begin{array}{l}\text { Monoclonal antibody } \\
\text { against IL-6R }\end{array}$ & Hindering IL-6 from exerting its pro-inflammatory effects. & [140] \\
\hline Canakinumab & $\mathrm{IL}-1 \beta$ & $\begin{array}{l}\text { Monoclonal antibody } \\
\text { against IL-1 } \beta\end{array}$ & Treatment of cryopyrin-associated periodic syndromes & [141] \\
\hline Infliximab & TNF-a & $\begin{array}{l}\text { Monoclonal antibody } \\
\text { against TNF-a }\end{array}$ & Treatment of autoimmune diseases & [142-144] \\
\hline Bevacizumab (Avastin) & VEGF & $\begin{array}{l}\text { Monoclonal antibody } \\
\text { against VEGF-A }\end{array}$ & Angiogenesis inhibitor & [145] \\
\hline AZD3695 & MCT1 & MCT1 inhibition & Reduce tumor growth, Increase intra-tumor lactate & [146] \\
\hline Nivolumab & PD-1 & $\begin{array}{l}\text { Monoclonal antibody } \\
\text { against PD-1 }\end{array}$ & Checkpoint inhibitor & [147] \\
\hline Durvalumab & PD-L1 & $\begin{array}{l}\text { Monoclonal antibody } \\
\text { against PD-L1 }\end{array}$ & $\begin{array}{l}\text { Blocking the interaction of PD-L1 with the PD-1 and } \\
\text { CD80 (B7.1) molecules. }\end{array}$ & [148] \\
\hline Avelumab & PD-L1 & $\begin{array}{l}\text { Monoclonal antibody } \\
\text { against PD-L1 }\end{array}$ & Blocking the interaction of PD-L1 binding to PD-1 & [149] \\
\hline
\end{tabular}

cancer, it may weaken the therapeutic effect of cancer treatments. For obesity, direct lifestyle intervention through diet and exercise may be the simplest and most effective strategy.

We believe that an in-depth understanding of exosomes in the tumor microenvironment may contribute to the design of cancer-diagnostic and cancer-prognostic tools. Effective therapeutic strategies for cancer using exosomes as drug carriers are expected in the near future.

\section{Abbreviations}

ACAT: Acetyl-CoA acetyltransferase; ADSCs: Adipose-derived stem cells; AKT: Protein kinase B; AMPK: Adenosine 5'-monophosphate (AMP)-activated protein kinase; APAF1: Apoptotic protease activating factor-1;

APN: Adiponectin; ATP: Adenosine triphosphate; BC: Breast cancer; BDH1: 3Hydroxybutyrate dehydrogenase 1; BMI: Body mass index; CAAs: Cancerassociated adipocytes; CAFs: Cancer-associated fibroblasts; Cav-1: Caveolin 1; CCL2: Chemokine (C-C motif) ligand 2; CCL5: Chemokine (C-C motif) ligand 5; CCR2,4,5: C-C motif chemokine receptor2,4,5; CLS: Crown-like structures; CSCs: Cancer stem cells; CXCL12: Chemokine (C-X-C motif) ligand 12; DIO: Dietary-induced obesity; ECs: Endothelial cells; ER: Estrogen receptor; FABPs: Fatty acid-binding proteins; FAO: Fatty acid oxidation; FATP1: Fatty acid transport protein-1; FFAs: Free fatty acids; FGF-2: Fibroblast growth factor-2; GDH: Glutamate dehydrogenase; GLS1: Glutaminase-1; gp130: Glycoprotein 130; HER2: Human epidermal growth factor receptor-2; HIF-1: Hypoxia-inducible factor-1; HMGCL: 3-Hydroxymethyl-3-methylglutarylCoA lyase; HMG-CoA: 3-Hydroxy-3-methyl glutaryl coenzyme A; HMGCS2: 3Hydroxy-3-methylglutaryl-CoA synthase 2; IL-1 $\beta$ : Interleukin-1 $\beta$; IL6: Interleukin-6; JAK: Janus kinase; MAPK: Mitogen-activated protein kinase; MCP-1: Monocyte chemoattractant protein-1; MCT4: Monocarboxylate transporter 4; MCTs: Monocarboxylate transporters; MGDAs: Mammaryderived adipocytes; MMP: Matrix metalloproteinases; MTOR: Mechanistic target of rapamycin; NF-kB: Nuclear factor kappa-B; NRP1: Neuropilin-1; OBR: Leptin receptor; OPG: Osteoprotegerin; OXCT: 3-Oxoacid CoA-transferase; OXPHOS: Oxidative phosphorylation; PD-L1: Programmed death-ligand 1; PI(3,4,5)P3: Phosphatidylinositol-3,4,5-trisphosphate; PI3K: Phosphatidylinositol 3-kinase; PPARY: Peroxisome proliferators-activated receptor $\gamma$; PRDM16: PR domain containing 16; PTHrP: Parathyroid hormone-related protein; RANKL: Receptor activator of nuclear factor kappa B ligand; RUNX3: Runt- related transcription factor 3; SRC: Steroid receptor coactivator; SREBP1: Sterol regulatory element-binding protein-1; STAT3: Signal transducer and activator of transcription 3; TAM: Tumor-associated macrophages;

TCA: Tricarboxylic acid; TGF- $\beta$ : Transforming growth factor- $\beta$; TNF- $a$ : Tumor necrosis factor-alpha; UCP1: Uncoupling protein 1; VEGF: Vascular endothelial growth factor

\section{Acknowledgements}

We thank a professional English editor (American Journal Experts) for assistance in improving the quality of language.

\section{Authors' contributions}

$Z \mathrm{~L}$ and $\mathrm{JL}$ are responsible for collecting and collating documents. QW and $\mathrm{BL}$ are responsible for writing this review, while SS is responsible for the revision and SS is responsible for editing and submission. All authors read and approved the final manuscript.

\section{Funding}

This work was supported by a National Natural Science Foundation of China (NSFC) grant (Grant No. 81471781) and a National major scientific instruments and equipment development projects grant (Grant No. 2012YQ160203) to Dr. Shengrong Sun.

Availability of data and materials

Not applicable.

Ethics approval and consent to participate

Does not apply as it is a review article.

Consent for publication

Not applicable.

\section{Competing interests}

The authors declare that they have no competing interests.

\section{Author details}

'Department of Breast and Thyroid Surgery, Renmin Hospital of Wuhan University, 238 Ziyang Road, Wuhan, Hubei, People's Republic of China. ${ }^{2}$ Metabolomics and Cell Biology Platforms, Gustave Roussy Comprehensive Cancer Institute, Villejuif, France. ${ }^{3}$ Faculty of Medicine, University of Paris Sud-Saclay, Kremlin-Bicêtre, France. ${ }^{4}$ Department of Clinical Laboratory, Renmin Hospital of Wuhan University, 238 Ziyang Road, Wuhan, Hubei, People's Republic of China. 
Received: 23 April 2019 Accepted: 19 August 2019

\section{Published online: 10 September 2019}

\section{References}

1. Dirat B, Bochet L, Dabek M, Daviaud D, Dauvillier S, Majed B, Wang YY, Meulle A, Salles B, Le Gonidec S, et al. Cancer-associated adipocytes exhibit an activated phenotype and contribute to breast cancer invasion. Cancer Res. 2011;71(7):2455-65.

2. Lapeire L, Hendrix A, Lambein K, Van Bockstal M, Braems G, Van Den Broecke R, Limame R, Mestdagh P, Vandesompele J, Vanhove C, et al. Cancer-associated adipose tissue promotes breast cancer progression by paracrine oncostatin M and Jak/STAT3 signaling. Cancer Res. 2014; 74(23):6806-19.

3. Wang YY, Attane C, Milhas D, Dirat B, Dauvillier S, Guerard A, Gilhodes J, Lazar I, Alet N, Laurent $V$, et al. Mammary adipocytes stimulate breast cancer invasion through metabolic remodeling of tumor cells. JCl Insight. 2017;2(4):e87489.

4. Attane C, Milhas D, Hoy AJ, Muller C. Metabolic remodeling induced by adipocytes: a new Achille heels in invasive breast cancer? Curr Med Chem; 2018.

5. Bussard KM, Mutkus L, Stumpf K, Gomez-Manzano C, Marini FC. Tumorassociated stromal cells as key contributors to the tumor microenvironment. Breast Cancer Res. 2016;18(1):84.

6. Fujisaki K, Fujimoto H, Sangai T, Nagashima T, Sakakibara M, Shiina N, Kuroda M, Aoyagi Y, Miyazaki M. Cancer-mediated adipose reversion promotes cancer cell migration via IL-6 and MCP-1. Breast Cancer Res Treat. 2015:150(2):255-63.

7. D'Esposito V, Liguoro D, Ambrosio MR, Collina F, Cantile M, Spinelli R, Raciti GA, Miele C, Valentino R, Campiglia P, et al. Adipose microenvironment promotes triple negative breast cancer cell invasiveness and dissemination by producing CCL5. Oncotarget. 2016;7(17):24495-509.

8. De Palma M, Biziato D, Petrova TV. Microenvironmental regulation of tumour angiogenesis. Nat Rev Cancer. 2017;17(8):457-74.

9. Melgarejo E, Medina MA, Sanchez-Jimenez F, Urdiales JL. Monocyte chemoattractant protein-1: a key mediator in inflammatory processes. Int $J$ Biochem Cell Biol. 2009;41(5):998-1001.

10. Santander AM, Lopez-Ocejo O, Casas O, Agostini T, Sanchez L, LamasBasulto E, Carrio R, Cleary MP, Gonzalez-Perez RR, Torroella-Kouri M. Paracrine interactions between adipocytes and tumor cells recruit and modify macrophages to the mammary tumor microenvironment: the role of obesity and inflammation in breast adipose tissue. Cancers (Basel). 2015; 7(1):143-78

11. Tsuyada A, Chow A, Wu J, Somlo G, Chu P, Loera S, Luu T, Li AX, Wu X, Ye $W$, et al. CCL2 mediates cross-talk between cancer cells and stromal fibroblasts that regulates breast cancer stem cells. Cancer Res. 2012;72(11): 2768-79.

12. Saji H, Koike M, Yamori T, Saji S, Seiki M, Matsushima K, Toi M. Significant correlation of monocyte chemoattractant protein-1 expression with neovascularization and progression of breast carcinoma. Cancer. 2001;92(5): 1085-91.

13. Ueno T, Toi M, Saji H, Muta M, Bando H, Kuroi K, Koike M, Inadera $H$, Matsushima K. Significance of macrophage chemoattractant protein-1 in macrophage recruitment, angiogenesis, and survival in human breast cancer. Clin Cancer Res. 2000;6(8):3282-9.

14. Arendt LM, McCready J, Keller PJ, Baker DD, Naber SP, Seewaldt V, Kuperwasser C. Obesity promotes breast cancer by CCL2-mediated macrophage recruitment and angiogenesis. Cancer Res. 2013;73(19): 6080-93.

15. Khalid A, Wolfram J, Ferrari I, Mu C, Mai J, Yang Z, Zhao Y, Ferrari M, Ma X, Shen $\mathrm{H}$. Recent advances in discovering the role of CCL5 in metastatic breast cancer. Mini Rev Med Chem. 2015;15(13):1063-72.

16. Karnoub AE, Dash AB, Vo AP, Sullivan A, Brooks MW, Bell GW, Richardson AL, Polyak K, Tubo R, Weinberg RA. Mesenchymal stem cells within tumour stroma promote breast cancer metastasis. Nature. 2007;449(7162):557-63.

17. Gao D, Rahbar R, Fish EN. CCL5 activation of CCR5 regulates cell metabolism to enhance proliferation of breast cancer cells. Open Biol. 2016; 6(6):160122

18. Velasco-Velazquez M, Jiao X, De La Fuente M, Pestell TG, Ertel A, Lisanti MP, Pestell RG. CCR5 antagonist blocks metastasis of basal breast cancer cells. Cancer Res. 2012;72(15):3839-50.

19. Sax MJ, Gasch C, Athota VR, Freeman R, Rasighaemi P, Westcott DE, Day CJ, Nikolic I, Elsworth B, Wei M, et al. Cancer cell CCL5 mediates bone marrow independent angiogenesis in breast cancer. Oncotarget. 2016;7(51):85437-49.

20. Velasco-Velazquez M, Pestell RG. The CCL5/CCR5 axis promotes metastasis in basal breast cancer. Oncoimmunology. 2013;2(4):e23660.

21. Kim EJ, Kim YK, Kim S, Kim JE, Tian YD, Doh EJ, Lee DH, Chung JH. Adipochemokines induced by ultraviolet irradiation contribute to impaired fat metabolism in subcutaneous fat cells. Br J Dermatol. 2018; 178(2):492-501.

22. Keophiphath M, Rouault C, Divoux A, Clement K, Lacasa D. CCL5 promotes macrophage recruitment and survival in human adipose tissue. Arterioscler Thromb Vasc Biol. 2010;30(1):39-45.

23. Shao L, Feng B, Zhang Y, Zhou H, Ji W, Min W. The role of adipose-derived inflammatory cytokines in type 1 diabetes. Adipocyte. 2016;5(3):270-4.

24. Guo Y, Xu F, Lu T, Duan Z, Zhang Z. Interleukin-6 signaling pathway in targeted therapy for cancer. Cancer Treat Rev. 2012;38(7):904-10.

25. Chan DS, Vieira AR, Aune D, Bandera EV, Greenwood DC, McTiernan A, Navarro Rosenblatt D, Thune I, Vieira R, Norat T. Body mass index and survival in women with breast cancer-systematic literature review and metaanalysis of 82 follow-up studies. Ann Oncol. 2014;25(10):1901-14.

26. Lee MJ, Wu Y, Fried SK. Adipose tissue remodeling in pathophysiology of obesity. Curr Opin Clin Nutr Metab Care. 2010;13(4):371-6.

27. Kim HS, Jung M, Choi SK, Woo J, Piao YJ, Hwang EH, Kim H, Kim SJ, Moon WK. IL-6-mediated cross-talk between human preadipocytes and ductal carcinoma in situ in breast cancer progression. J Exp Clin Cancer Res. 2018:37(1):200

28. Jin K, Pandey NB, Popel AS. Simultaneous blockade of IL-6 and CCL5 signaling for synergistic inhibition of triple-negative breast cancer growth and metastasis. Breast Cancer Res. 2018;20(1):54.

29. Guo C, Chen Y, Gao W, Chang A, Ye Y, Shen W, Luo Y, Yang S, Sun P, Xiang $\mathrm{R}$, et al. Liposomal nanoparticles carrying anti-IL6R antibody to the tumour microenvironment inhibit metastasis in two molecular subtypes of breast cancer mouse models. Theranostics. 2017;7(3):775-88.

30. Deng T, Lyon CJ, Bergin S, Caligiuri MA, Hsueh WA. Obesity, inflammation, and cancer. Annu Rev Pathol. 2016;11:421-49.

31. Liu S, Lee JS, Jie C, Park MH, Iwakura Y, Patel Y, Soni M, Reisman D, Chen H. HER2 overexpression triggers an IL1alpha proinflammatory circuit to drive tumorigenesis and promote chemotherapy resistance. Cancer Res. 2018; 78(8):2040-51.

32. Banerjee $\mathrm{K}$, Resat $\mathrm{H}$. Constitutive activation of STAT3 in breast cancer cells: a review. Int J Cancer. 2016;138(11):2570-8.

33. Shen Q, Cohen B, Zheng W, Rahbar R, Martin B, Murakami K, Lamorte S, Thompson P, Berman H, Zuniga-Pflucker JC, et al. Notch shapes the innate immunophenotype in breast cancer. Cancer Discov. 2017;7(11):1320-35.

34. Stender JD, Nwachukwu JC, Kastrati I, Kim Y, Strid T, Yakir M, Srinivasan S, Nowak J, Izard T, Rangarajan ES, et al. Structural and molecular mechanisms of cytokine-mediated endocrine resistance in human breast cancer cells. Mol Cell. 2017:65(6):1122-35 e1125.

35. Tulotta C, Ottewell P. The role of IL-1B in breast cancer bone metastasis. Endocr Relat Cancer. 2018:25(7):R421-34.

36. Choi J, Cha YJ, Koo JS. Adipocyte biology in breast cancer: from silent bystander to active facilitator. Prog Lipid Res. 2018;69:11-20.

37. Liu D, Wang $X$, Chen $Z$. Tumor necrosis factor-alpha, a regulator and therapeutic agent on breast cancer. Curr Pharm Biotechnol. 2016;17(6): 486-94.

38. Hagemann T, Wilson J, Kulbe $H$, Li NF, Leinster DA, Charles K, Klemm F, Pukrop T, Binder C, Balkwill FR. Macrophages induce invasiveness of epithelial cancer cells via NF-kappa B and JNK. J Immunol. 2005;175(2): 1197-205.

39. Chua HL, Bhat-Nakshatri P, Clare SE, Morimiya A, Badve S, Nakshatri H. NFkappaB represses E-cadherin expression and enhances epithelial to mesenchymal transition of mammary epithelial cells: potential involvement of ZEB-1 and ZEB-2. Oncogene. 2007;26(5):711-24.

40. Johnston DA, Dong B, Hughes CC. TNF induction of jagged-1 in endothelial cells is NFkappaB-dependent. Gene. 2009:435(1-2):36-44.

41. Akiyama M, Hideshima T, Hayashi T, Tai YT, Mitsiades CS, Mitsiades N, Chauhan D, Richardson P, Munshi NC, Anderson KC. Nuclear factor-kappaB p65 mediates tumor necrosis factor alpha-induced nuclear translocation of telomerase reverse transcriptase protein. Cancer Res. 2003;63(1):18-21.

42. Zhu G, Du Q, Wang X, Tang N, She F, Chen Y. TNF-alpha promotes gallbladder cancer cell growth and invasion through autocrine mechanisms. Int J Mol Med. 2014;33(6):1431-40. 
43. Ferrara N, Gerber HP, LeCouter J. The biology of VEGF and its receptors. Nat Med. 2003;9(6):669-76.

44. Park J, Kim M, Sun K, An YA, Gu X, Scherer PE. VEGF-A-expressing adipose tissue shows rapid beiging and enhanced survival after transplantation and confers IL-4-independent metabolic improvements Diabetes. 2017:66(6):1479-90.

45. Kiso M, Tanaka S, Saji S, Toi M, Sato F. Long isoform of VEGF stimulates cell migration of breast cancer by filopodia formation via NRP1/ARHGAP17/ Cdc42 regulatory network. Int J Cancer. 2018;143(11):2905-18.

46. Incio J, Ligibel JA, McManus DT, Suboj P, Jung K, Kawaguchi K, Pinter M, Babykutty S, Chin SM, Vardam TD, et al. Obesity promotes resistance to antiVEGF therapy in breast cancer by up-regulating IL-6 and potentially FGF-2. Sci Transl Med. 2018;10(432)

47. Ando S, Barone I, Giordano C, Bonofiglio D, Catalano S. The multifaceted mechanism of leptin signaling within tumor microenvironment in driving breast cancer growth and progression. Front Oncol. 2014;4:340.

48. Okumura M, Yamamoto M, Sakuma H, Kojima T, Maruyama T, Jamali M, Cooper DR, Yasuda K. Leptin and high glucose stimulate cell proliferation in MCF-7 human breast cancer cells: reciprocal involvement of PKC-alpha and PPAR expression. Biochim Biophys Acta. 2002;1592(2):107-16.

49. Zhou W, Guo S, Gonzalez-Perez RR. Leptin pro-angiogenic signature in breast cancer is linked to IL-1 signalling. Br J Cancer. 2011;104(1):128-37.

50. Yin $N$, Wang $D$, Zhang $H$, Yi $X$, Sun $X$, Shi B, Wu H, Wu G, Wang $X$, Shang $Y$. Molecular mechanisms involved in the growth stimulation of breast cancer cells by leptin. Cancer Res. 2004;64(16):5870-5.

51. Picon-Ruiz M, Morata-Tarifa C, Valle-Goffin JJ, Friedman ER, Slingerland JM. Obesity and adverse breast cancer risk and outcome: mechanistic insights and strategies for intervention. CA Cancer J Clin. 2017;67(5):378-97.

52. Chan GK, Deckelbaum RA, Bolivar I, Goltzman D, Karaplis AC. PTHrP inhibits adipocyte differentiation by down-regulating PPAR gamma activity via a MAPK-dependent pathway. Endocrinology. 2001;142(11):4900-9.

53. Kir S, White JP, Kleiner S, Kazak L, Cohen P, Baracos VE, Spiegelman BM. Tumour-derived PTH-related protein triggers adipose tissue browning and cancer cachexia. Nature. 2014:513(7516):100-4

54. Miki T, Yano S, Hanibuchi M, Kanematsu T, Muguruma H, Sone S. Parathyroid hormone-related protein (PTHrP) is responsible for production of bone metastasis, but not visceral metastasis, by human small cell lung cancer SBC-5 cells in natural killer cell-depleted SCID mice. Int J Cancer. 2004;108(4):511-5.

55. Fan Y, Hanai Jl, Le PT, Bi R, Maridas D, DeMambro V, Figueroa CA, Kir S, Zhou X, Mannstadt M, et al. Parathyroid hormone directs bone marrow mesenchymal cell fate. Cell Metab. 2017;25(3):661-72.

56. Cairns RA, Harris IS, Mak TW. Regulation of cancer cell metabolism. Nat Rev Cancer. 2011:11(2):85-95.

57. Warburg O. On the origin of cancer cells. Science. 1956;123(3191):309-14.

58. Vander Heiden MG, Cantley LC, Thompson CB. Understanding the Warburg effect: the metabolic requirements of cell proliferation. Science. 2009; 324(5930):1029-33.

59. Schild T, Low V, Blenis J, Gomes AP. Unique metabolic adaptations dictate distal organ-specific metastatic colonization. Cancer Cell. 2018;33(3):347-54.

60. Wen YA, Xing X, Harris JW, Zaytseva YY, Mitov MI, Napier DL, Weiss HL, Mark Evers B, Gao T. Adipocytes activate mitochondrial fatty acid oxidation and autophagy to promote tumor growth in colon cancer. Cell Death Dis. 2017; 8(2):e2593.

61. Ladanyi A, Mukherjee A, Kenny HA, Johnson A, Mitra AK, Sundaresan S, Nieman KM, Pascual G, Benitah SA, Montag A, et al. Adipocyte-induced CD36 expression drives ovarian cancer progression and metastasis. Oncogene. 2018;37(17):2285-301.

62. Nieman KM, Kenny HA, Penicka CV, Ladanyi A, Buell-Gutbrod R, Zillhardt MR, Romero IL, Carey MS, Mills GB, Hotamisligil GS, et al. Adipocytes promote ovarian cancer metastasis and provide energy for rapid tumor growth. Nat Med. 2011;17(11):1498-503.

63. Chiavarina B, Whitaker-Menezes D, Martinez-Outschoorn UE, Witkiewicz AK, Birbe R, Howell A, Pestell RG, Smith J, Daniel R, Sotgia F, et al. Pyruvate kinase expression (PKM1 and PKM2) in cancer-associated fibroblasts drives stromal nutrient production and tumor growth. Cancer Biol Ther. 2011; 12(12):1101-13.

64. Kumar D, New J, Vishwakarma V, Joshi R, Enders J, Lin F, Dasari S, Gutierrez WR, Leef G, Ponnurangam S, et al. Cancer-associated fibroblasts drive glycolysis in a targetable signaling loop implicated in head and neck squamous cell carcinoma progression. Cancer Res. 2018;78(14):3769-82.
65. Sotgia F, Martinez-Outschoorn UE, Pavlides S, Howell A, Pestell RG, Lisanti MP. Understanding the Warburg effect and the prognostic value of stromal caveolin-1 as a marker of a lethal tumor microenvironment. Breast Cancer Res. 2011;13(4):213.

66. Wu Q, Li J, Li Z, Sun S, Zhu S, Wang L, Wu J, Yuan J, Zhang Y, Sun S, et al. Exosomes from the tumour-adipocyte interplay stimulate beige/ brown differentiation and reprogram metabolism in stromal adipocytes to promote tumour progression. J Exp Clin Cancer Res. 2019:38(1):223

67. Singh R, Parveen M, Basgen JM, Fazel S, Meshesha MF, Thames EC, Moore B, Martinez L, Howard CB, Vergnes $L$, et al. Increased expression of beige/ brown adipose markers from host and breast cancer cells influence xenograft formation in mice. Mol Cancer Res. 2016;14(1):78-92.

68. Petruzzelli M, Schweiger M, Schreiber R, Campos-Olivas R, Tsoli M, Allen J, Swarbrick M, Rose-John S, Rincon M, Robertson G, et al. A switch from white to brown fat increases energy expenditure in cancer-associated cachexia. Cell Metab. 2014;20(3):433-47.

69. Wilde L, Roche M, Domingo-Vidal M, Tanson K, Philp N, Curry J, MartinezOutschoorn U. Metabolic coupling and the reverse Warburg effect in cancer: implications for novel biomarker and anticancer agent development. Semin Oncol. 2017;44(3):198-203.

70. Pinheiro C, Longatto-Filho A, Azevedo-Silva J, Casal M, Schmitt FC, Baltazar F. Role of monocarboxylate transporters in human cancers: state of the art. Bioenerg Biomembr. 2012;44(1):127-39.

71. Li Z, Wu Q, Sun S, Wu J, Li J, Zhang Y, Wang C, Yuan J, Sun S. Monocarboxylate transporters in breast cancer and adipose tissue are novel biomarkers and potential therapeutic targets. Biochem Biophys Res Commun. 2018;501(4):962-7.

72. Huang CK, Chang PH, Kuo WH, Chen CL, Jeng YM, Chang KJ, Shew JY, Hu $\mathrm{CM}$, Lee WH. Adipocytes promote malignant growth of breast tumours with monocarboxylate transporter 2 expression via beta-hydroxybutyrate. Nat Commun. 2017:8:14706.

73. Nwosu ZC, Ebert MP, Dooley S, Meyer C. Caveolin-1 in the regulation of cell metabolism: a cancer perspective. Mol Cancer. 2016;15(1):71.

74. Pavlides S, Whitaker-Menezes D, Castello-Cros R, Flomenberg N, Witkiewicz AK, Frank PG, Casimiro MC, Wang C, Fortina P, Addya S, et al. The reverse Warburg effect: aerobic glycolysis in cancer associated fibroblasts and the tumor stroma. Cell Cycle. 2009;8(23):3984-4001.

75. Pope BD, Warren CR, Parker KK, Cowan CA. Microenvironmental control of adipocyte fate and function. Trends Cell Biol. 2016;26(10):745-55.

76. Hoy AJ, Balaban S, Saunders DN. Adipocyte-tumor cell metabolic crosstalk in breast cancer. Trends Mol Med. 2017;23(5):381-92.

77. Zaidi N, Lupien L, Kuemmerle NB, Kinlaw WB, Swinnen JV, Smans K. Lipogenesis and lipolysis: the pathways exploited by the cancer cells to acquire fatty acids. Prog Lipid Res. 2013:52(4):585-9.

78. Zhang M, Di Martino JS, Bowman RL, Campbell NR, Baksh SC, SimonVermot T, Kim IS, Haldeman P, Mondal C, Yong-Gonzalez V, et al. Adipocyte-derived lipids mediate melanoma progression via FATP proteins. Cancer Discov. 2018:8(8):1006-25.

79. Shafat MS, Oellerich T, Mohr S, Robinson SD, Edwards DR, Marlein CR, Piddock RE, Fenech M, Zaitseva L, Abdul-Aziz A, et al. Leukemic blasts program bone marrow adipocytes to generate a pro-tumoral microenvironment. Blood. 2017:129(10):1320-32.

80. Jethwa N, Chung GH, Lete MG, Alonso A, Byrne RD, Calleja V, Larijani B. Endomembrane Ptdlns(3,4,5)P3 activates the PI3K-Akt pathway. J Cell Sci. 2015;128(18):3456-65.

81. Lopes-Coelho F, Andre S, Felix A, Serpa J. Breast cancer metabolic cross-talk: fibroblasts are hubs and breast cancer cells are gatherers of lipids. Mol Cell Endocrinol. 2018;462(Pt B):93-106.

82. Guaita-Esteruelas S, Guma J, Masana L, Borras J. The peritumoural adipose tissue microenvironment and cancer. The roles of fatty acid binding protein 4 and fatty acid binding protein 5. Mol Cell Endocrinol. 2018;462(Pt B):107118.

83. Guaita-Esteruelas S, Bosquet A, Saavedra P, Guma J, Girona J, Lam EW, Amillano K, Borras J, Masana L. Exogenous FABP4 increases breast cancer cell proliferation and activates the expression of fatty acid transport proteins. Mol Carcinog. 2017;56(1):208-17.

84. Guaita-Esteruelas S, Saavedra-Garcia P, Bosquet A, Borras J, Girona J, Amiliano K, Rodriguez-Balada M, Heras M, Masana L, Guma J. Adiposederived fatty acid-binding proteins plasma concentrations are increased in breast cancer patients. Oncologist. 2017;22(11):1309-15. 
85. Hao J, Yan F, Zhang Y, Triplett A, Zhang Y, Schultz DA, Sun Y, Zeng J, Silverstein KAT, Zheng $\mathrm{Q}$, et al. Expression of adipocyte/macrophage fatty acid binding protein in tumor associated macrophages promotes breast cancer progression. Cancer Res. 2018;78(9):2343-55.

86. Yang D, Li Y, Xing L, Tan Y, Sun J, Zeng B, Xiang T, Tan J, Ren G, Wang Y. Utilization of adipocyte-derived lipids and enhanced intracellular trafficking of fatty acids contribute to breast cancer progression. Cell Commun Signal. 2018:16(1):32.

87. Liu RZ, Graham K, Glubrecht DD, Germain DR, Mackey JR, Godbout R. Association of FABP5 expression with poor survival in triple-negative breast cancer: implication for retinoic acid therapy. Am J Pathol. 2011; 178(3):997-1008.

88. Martinez-Outschoorn UE, Lin Z, Whitaker-Menezes D, Howell A, Sotgia F, Lisanti MP. Ketone body utilization drives tumor growth and metastasis. Cell Cycle. 2012;11(21):3964-71.

89. Martinez-Outschoorn UE, Peiris-Pages M, Pestell RG, Sotgia F, Lisanti MP. Cancer metabolism: a therapeutic perspective. Na Rev Clin Oncol. 2017; 14(1):11-31.

90. Rodriques LM, Uribe-Lewis S, Madhu B, Honess DJ, Stubbs M, Griffiths JR. The action of beta-hydroxybutyrate on the growth, metabolism and global histone $\mathrm{H} 3$ acetylation of spontaneous mouse mammary tumours: evidence of a beta-hydroxybutyrate paradox. Cancer Metab. 2017;5:4.

91. Martinez-Outschoorn UE, Lisanti MP, Sotgia F. Catabolic cancer-associated fibroblasts transfer energy and biomass to anabolic cancer cells, fueling tumor growth. Semin Cancer Biol. 2014;25:47-60.

92. Martinez-Outschoorn UE, Lin Z, Whitaker-Menezes D, Howell A, Lisanti MP, Sotgia F. Ketone bodies and two-compartment tumor metabolism: stromal ketone production fuels mitochondrial biogenesis in epithelial cancer cells. Cell Cycle. 2012;11(21):3956-63.

93. Shukla SK, Gebregiworgis T, Purohit V, Chaika NV, Gunda V, Radhakrishnan P, Mehla K, Pipinos II, Powers R, Yu F, et al. Metabolic reprogramming induced by ketone bodies diminishes pancreatic cancer cachexia. Cancer Metab. 2014;2:18.

94. Sanchez-Alvarez R, Martinez-Outschoorn UE, Lamb R, Hulit J, Howell A, Gandara R, Sartini M, Rubin E, Lisanti MP, Sotgia F. Mitochondrial dysfunction in breast cancer cells prevents tumor growth: understanding chemoprevention with metformin. Cell Cycle. 2013;12(1):172-82.

95. Tsun ZY, Possemato R. Amino acid management in cancer. Semin Cell Dev Biol. 2015;43:22-32.

96. Lyssiotis CA, Kimmelman AC. Metabolic interactions in the tumor microenvironment. Trends Cell Biol. 2017;27(11):863-75.

97. Villar VH, Merhi F, Djavaheri-Mergny M, Duran RV. Glutaminolysis and autophagy in cancer. Autophagy. 2015;11(8):1198-208.

98. Altman BJ, Stine ZE, Dang CV. From Krebs to clinic: glutamine metabolism to cancer therapy. Nat Rev Cancer. 2016;16(12):773.

99. Zhang J, Pavlova NN, Thompson CB. Cancer cell metabolism: the essential role of the nonessential amino acid, glutamine. Embo J. 2017;36(10):1302-15.

100. Yang L, Achreja A, Yeung TL, Mangala LS, Jiang D, Han C, Baddour J, Marini JC, Ni J, Nakahara R, et al. Targeting stromal glutamine synthetase in tumors disrupts tumor microenvironment-regulated cancer cell growth. Cell Metab. 2016;24(5):685-700.

101. Ko YH, Lin Z, Flomenberg N, Pestell RG, Howell A, Sotgia F, Lisanti MP, Martinez-Outschoorn UE. Glutamine fuels a vicious cycle of autophagy in the tumor stroma and oxidative mitochondrial metabolism in epithelial cancer cells: implications for preventing chemotherapy resistance. Cancer Biol Ther. 2011;12(12):1085-97.

102. Tardito S, Oudin A, Ahmed SU, Fack F, Keunen O, Zheng L, Miletic H, Sakariassen $P O$, Weinstock A, Wagner A, et al. Glutamine synthetase activity fuels nucleotide biosynthesis and supports growth of glutamine-restricted glioblastoma. Nat Cell Biol. 2015;17(12):1556-68.

103. Sousa CM, Biancur DE, Wang $X$, Halbrook CJ, Sherman MH, Zhang L, Kremer D, Hwang RF, Witkiewicz AK, Ying $H$, et al. Pancreatic stellate cells support tumour metabolism through autophagic alanine secretion. Nature. 2016; 536(7617):479-83.

104. Spinelli JB, Yoon H, Ringel AE, Jeanfavre S, Clish CB, Haigis MC. Metabolic recycling of ammonia via glutamate dehydrogenase supports breast cancer biomass. Science. 2017;358(6365):941-6.

105. Valencia T, Kim JY, Abu-Baker S, Moscat-Pardos J, Ahn CS, Reina-Campos M, Duran A, Castilla EA, Metallo CM, Diaz-Meco MT, et al. Metabolic reprogramming of stromal fibroblasts through p62-mTORC1 signaling promotes inflammation and tumorigenesis. Cancer Cell. 2014;26(1):121-35.
106. Huang J, Duran A, Reina-Campos M, Valencia T, Castilla EA, Muller TD, Tschop MH, Moscat J, Diaz-Meco MT. Adipocyte p62/SQSTM1 suppresses tumorigenesis through opposite regulations of metabolism in adipose tissue and tumor. Cancer Cell. 2018;33(4):770-84 e776.

107. Salimian Rizi B, Caneba C, Nowicka A, Nabiyar AW, Liu X, Chen K, Klopp A, Nagrath D. Nitric oxide mediates metabolic coupling of omentum-derived adipose stroma to ovarian and endometrial cancer cells. Cancer Res. 2015; 75(2):456-71.

108. Sullivan LB, Chandel NS. Mitochondrial reactive oxygen species and cancer. Cancer Metab. 2014;2(1):17.

109. Wang W, Kryczek I, Dostal L, Lin H, Tan L, Zhao L, Lu F, Wei S, Maj T, Peng $D$, et al. Effector $T$ cells abrogate stroma-mediated chemoresistance in ovarian cancer. Cell. 2016;165(5):1092-105.

110. Tkach $\mathrm{M}$, Thery C. Communication by extracellular vesicles: where we are and where we need to go. Cell. 2016;164(6):1226-32.

111. Milane L, Singh A, Mattheolabakis G, Suresh M, Amiji MM. Exosome mediated communication within the tumor microenvironment. J Control Release. 2015;219:278-94.

112. Minciacchi VR, Freeman MR, Di Vizio D. Extracellular vesicles in cancer: exosomes, microvesicles and the emerging role of large oncosomes. Semin Cell Dev Biol. 2015:40:41-51.

113. Gandellini P, Doldi V. Zaffaroni N: microRNAs as players and signals in the metastatic cascade: implications for the development of novel antimetastatic therapies. Semin Cancer Biol. 2017;44:132-40.

114. Zhang Y, Wang XF. A niche role for cancer exosomes in metastasis. Nat Cell Biol. 2015;17(6):709-11.

115. Wu Q, Sun S, Li Z, Yang Q, Li B, Zhu S, Wang L, Wu J, Yuan J, Yang C, et al. Tumour-originated exosomal miR-155 triggers cancer-associated cachexia to promote tumour progression. Mol Cancer. 2018;17(1):155.

116. Fong MY, Zhou W, Liu L, Alontaga AY, Chandra M, Ashby J, Chow A, O'Connor ST, Li S, Chin AR, et al. Breast-cancer-secreted miR-122 reprograms glucose metabolism in premetastatic niche to promote metastasis. Nat Cell Biol. 2015;17(2):183-94

117. Yan W, Wu X, Zhou W, Fong MY, Cao M, Liu J, Liu X, Chen CH, Fadare O, Pizzo DP, et al. Cancer-cell-secreted exosomal miR-105 promotes tumour growth through the MYC-dependent metabolic reprogramming of stromal cells. Nat Cell Biol. 2018;20(5):597-609.

118. Wang S, Xu M, Li X, Su X, Xiao X, Keating A, Zhao RC. Exosomes released by hepatocarcinoma cells endow adipocytes with tumor-promoting properties. J Hematol Oncol. 2018;11(1):82.

119. Sagar G, Sah RP, Javeed N, Dutta SK, Smyrk TC, Lau JS, Giorgadze N, Tchkonia T, Kirkland JL, Chari ST, et al. Pathogenesis of pancreatic cancer exosome-induced lipolysis in adipose tissue. Gut. 2016;65(7):1165-74.

120. Zhang H, Zhu L, Bai M, Liu Y, Zhan Y, Deng T, Yang H, Sun W, Wang $X$, Zhu $\mathrm{K}$, et al. Exosomal circRNA derived from gastric tumor promotes white adipose browning by targeting the miR-133/PRDM16 pathway. Int J Cancer. 2019;144(10):2501-15.

121. Kogo R, Shimamura T, Mimori K, Kawahara K, Imoto S, Sudo T, Tanaka F, Shibata K, Suzuki A, Komune S, et al. Long noncoding RNA HOTAIR regulates polycomb-dependent chromatin modification and is associated with poor prognosis in colorectal cancers. Cancer Res. 2011;71(20):6320-6.

122. Gupta RA, Shah N, Wang KC, Kim J, Horlings HM, Wong DJ, Tsai MC, Hung $T$, Argani $P$, Rinn JL, et al. Long non-coding RNA HOTAIR reprograms chromatin state to promote cancer metastasis. Nature. 2010; 464(7291):1071-6.

123. Ma X, Li Z, Li T, Zhu L, Li Z, Tian N. Long non-coding RNA HOTAIR enhances angiogenesis by induction of VEGFA expression in glioma cells and transmission to endothelial cells via glioma cell derived-extracellular vesicles. Am J Transl Res. 2017;9(11):5012-21.

124. Lazar I, Clement E, Dauvillier S, Milhas D, Ducoux-Petit M, LeGonidec S, Moro C, Soldan V, Dalle S, Balor S, et al. Adipocyte exosomes promote melanoma aggressiveness through fatty acid oxidation: a novel mechanism linking obesity and cancer. Cancer Res. 2016;76(14):4051-7.

125. Wang J, Wu Y, Guo J, Fei X, Yu L, Ma S. Adipocyte-derived exosomes promote lung cancer metastasis by increasing MMP9 activity via transferring MMP3 to lung cancer cells. Oncotarget. 2017:8(47):81880-91.

126. MacKenzie TA, Schwartz GN, Calderone HM, Graveel CR, Winn ME, Hostetter G, Wells WA, Sempere LF. Stromal expression of miR-21 identifies high-risk group in triple-negative breast cancer. Am J Pathol. 2014;184(12):3217-25.

127. Bhome R, Goh RW, Bullock MD, Pillar N, Thirdborough SM, Mellone M, Mirnezami R, Galea D, Veselkov K, Gu Q, et al. Exosomal microRNAs derived 
from colorectal cancer-associated fibroblasts: role in driving cancer progression. Aging (Albany NY). 2017;9(12):2666-94.

128. Au Yeung CL, Co NN, Tsuruga T, Yeung TL, Kwan SY, Leung CS, Li Y, Lu ES, Kwan K, Wong KK, et al. Exosomal transfer of stroma-derived miR21 confers paclitaxel resistance in ovarian cancer cells through targeting APAF1. Nat Commun. 2016;7:11150.

129. Camps C, Buffa FM, Colella S, Moore J, Sotiriou C, Sheldon H, Harris AL, Gleadle JM. Ragoussis J: hsa-miR-210 Is induced by hypoxia and is an independent prognostic factor in breast cancer. Clin Cancer Res. 2008; 14(5):1340-8.

130. Bar I, Merhi A, Abdel-Sater F, Ben Addi A, Sollennita S, Canon JL, Delree P. The microRNA miR-210 is expressed by cancer cells but also by the tumor microenvironment in triple-negative breast cancer. J Histochem Cytochem. 2017;22155417702849

131. Zheng Z, Liu L, Zhan Y, Yu S, Kang T. Adipose-derived stem cell-derived microvesicle-released miR-210 promoted proliferation, migration and invasion of endothelial cells by regulating RUNX3. Cell Cycle. 2018;17(8): 1026-33.

132. Wu B, Sun X, Gupta HB, Yuan B, Li J, Ge F, Chiang HC, Zhang X, Zhang C, Zhang D, et al. Adipose PD-L1 modulates PD-1/PD-L1 checkpoint blockade immunotherapy efficacy in breast cancer. Oncoimmunology. 2018;7(11):e1500107.

133. Pandolfi JB, Ferraro AA, Sananez I, Gancedo MC, Baz P, Billordo LA, Fainboim $\mathrm{L}$, Arruvito L. ATP-induced inflammation drives tissue-resident Th17 cells in metabolically unhealthy obesity. J Immunol. 2016;196(8):3287-96.

134. Perrier S, Caldefie-Chezet F, Vasson MP. IL-1 family in breast cancer: potential interplay with leptin and other adipocytokines. FEBS letters. 2009; 583(2):259-65.

135. Koru-Sengul T, Santander AM, Miao F, Sanchez LG, Jorda M, Gluck S, Ince TA, Nadji M, Chen Z, Penichet ML, et al. Breast cancers from black women exhibit higher numbers of immunosuppressive macrophages with proliferative activity and of crown-like structures associated with lower survival compared to non-black Latinas and Caucasians. Breast Cancer Res Treat. 2016;158(1):113-26.

136. Stokes L, Surprenant A. Purinergic P2Y2 receptors induce increased MCP-1/ CCL2 synthesis and release from rat alveolar and peritoneal macrophages. J Immunol. 2007;179(9):6016-23.

137. Guicciardi ME, Trussoni CE, Krishnan A, Bronk SF, Lorenzo Pisarello MJ, O'Hara SP, Splinter PL, Gao Y, Vig P, Revzin A, et al. Macrophages contribute to the pathogenesis of sclerosing cholangitis in mice. $J$ Hepatol. 2018;69(3):676-86.

138. Klibanov OM, Williams SH, Iler CA. Cenicriviroc, an orally active CCR5 antagonist for the potential treatment of HIV infection. Curr Opin Investig Drugs. 2010;11(8):940-50

139. Levy JA. HIV pathogenesis: 25 years of progress and persistent challenges. AIDS. 2009;23(2):147-60.

140. Jones G, Sebba A, Gu J, Lowenstein MB, Calvo A, Gomez-Reino JJ, Siri DA, Tomsic M, Alecock E, Woodworth T, et al. Comparison of tocilizumab monotherapy versus methotrexate monotherapy in patients with moderate to severe rheumatoid arthritis: the AMBITION study. Ann Rheum Dis. 2010;69(1):88-96.

141. Brogan PA, Hofer M, Kuemmerle-Deschner JB, Kone-Paut I, Roesler J, Kallinich T, Horneff G, Calvo Penades I, Sevilla-Perez B, Goffin L, et al. Canakinumab provides rapid and sustained long-term efficacy and safety in patients with cryopyrin-associated periodic syndrome aged $\leq 5$ years. Arthritis Rheumatol. 2019. Epub ahead of print.

142. Present DH, Rutgeerts $P$, Targan S, Hanauer SB, Mayer L, van Hogezand RA Podolsky DK, Sands BE, Braakman T, DeWoody KL, et al. Infliximab for the treatment of fistulas in patients with Crohn's disease. N Engl J Med. 1999; 340(18):1398-405.

143. Rutgeerts P, Sandborn WJ, Feagan BG, Reinisch W, Olson A, Johanns J, Travers S, Rachmilewitz D, Hanauer SB, Lichtenstein GR, et al. Infliximab for induction and maintenance therapy for ulcerative colitis. N Engl J Med. 2005;353(23):2462-76.

144. Blumenauer B, Judd M, Wells G, Burls A, Cranney A, Hochberg M, Tugwell P. Infliximab for the treatment of rheumatoid arthritis. Cochrane Database Syst Rev. 2002;3:CD003785.

145. Shih T, Lindley C. Bevacizumab: an angiogenesis inhibitor for the treatment of solid malignancies. Clin Ther. 2006;28(11):1779-802.

146. Polanski R, Hodgkinson CL, Fusi A, Nonaka D, Priest L, Kelly P, Trapani F, Bishop PW, White A, Critchlow SE, et al. Activity of the monocarboxylate transporter 1 inhibitor AZD3965 in small cell lung cancer. Clin Cancer Res. 2014;20(4):926-37.

147. Bekoz H, Karadurmus N, Paydas S, Turker A, Toptas T, Firatli Tuglular T, Sonmez M, Gulbas Z, Tekgunduz E, Kaya AH, et al. Nivolumab for relapsed or refractory Hodgkin lymphoma: real-life experience. Ann Oncol. 2017; 28(10):2496-502.

148. Antonia SJ, Balmanoukian A, Brahmer J, Ou SI, Hellmann MD, Kim SW, Ahn MJ, Kim DW, Gutierrez M, Liu SV, et al. Clinical activity, tolerability, and longterm follow-up of Durvalumab in patients with advanced NSCLC. J Thorac Oncol. 2019. Epub ahead of print.

149. Hamilton G, Rath B. Avelumab: combining immune checkpoint inhibition and antibody-dependent cytotoxicity. Expert Opin Biol Ther. 2017:17(4):515-23.

\section{Publisher's Note}

Springer Nature remains neutral with regard to jurisdictional claims in published maps and institutional affiliations.

Ready to submit your research? Choose BMC and benefit from:

- fast, convenient online submission

- thorough peer review by experienced researchers in your field

- rapid publication on acceptance

- support for research data, including large and complex data types

- gold Open Access which fosters wider collaboration and increased citations

- maximum visibility for your research: over $100 \mathrm{M}$ website views per year

At $\mathrm{BMC}$, research is always in progress.

Learn more biomedcentral.com/submissions 